\title{
Study on Temperature Gradients and Protein Enrichment by Aspergillus oryzae in Solid-State Fermentation on Packed Bed Bioreactor Using Jowar (Sorghum) Straw as Substrate
}

\author{
Ganesh A. Bathe $^{1 *}$, Vilas S. Patil ${ }^{1}$, Ashish S. Chaurasia ${ }^{2 *}$ \\ ${ }^{1}$ School of Chemical Technology, North Maharashtra University, Jalgaon, India \\ ${ }^{2}$ Department of Chemical Engineering, Jaypee University of Engineering and Technology, Guna, India \\ Email: "ganeshbathe@yahoo.com, *ashishchaurasia1@yahoo.com
}

Received July 18, 2012; revised August 20, 2012; accepted August 29, 2012

\begin{abstract}
The packed bed solid state bioreactor designated as PBSSB is constructed in the present study. The experiments are carried out in packed bed bioreactor with jowar straw and inoculated with Aspergillus oryzae. Temperature gradient has been measured at different axial positions. It is found that the organisms grew rapidly during the period from 20 to $30 \mathrm{~h}$ during which heat generation is more. These results are in agreement with other researchers. The fermented jowar straw shows threefold increase in protein content. This can be utilized as high value nutritional feed to animals.
\end{abstract}

Keywords: Solid-State Fermentation; Packed-Bed Bioreactor; Aspergillus oryzae; Jowar Straw; Temperature Gradient

\section{Introduction}

India is an agrarian country. Around $60 \%-65 \%$ of the people directly or indirectly depend upon agriculture. The Indian farmer community is facing very serious economic crises due to unpredictable monsoon, low market value for agro-product, etc. Pressure of economic crises on agro-based industries can be reduced up to certain level if scientific research will be concentrated more in these areas. Solid state fermentation can be a potential solution for upgrading the nutritive value of agricultural products and has the possibility of having it carried out on farms [1]. If solid state fermentation (SSF) can be used efficiently for large capacity then we can serve in better way for society. Overall efficiency of the solid state fermentation (SSF) basically depends on three factors i.e. Energy, Economy and Environment.

Submerged fermentation (SmF) and solid state fermentation (SSF) are the two bioconversion methods in operation. Submerged fermentation (SmF) is well established while the solid state fermentation (SSF) is still in evolutionary state and under intensive research. Solid state fermentation has been defined as the fermentation on moist substrate and is carried out in the absence or near absence of free water [2,3]. In this process, water is present in the solid substrate whose capacity for liquid

${ }^{*}$ Corresponding authors. retention varies with the type of biomass material.

The bioreactors for solid-state fermentation can be divided into four types, based on type of aeration or the mixed system employed [4]. These are tray column, packed-bed column, rotating drum and fluidized bed column. Heat accumulation is the serious problem in the solid state fermentor and is the major consideration in the design of large scale packed bed solid state bioreactor (PBSSB). Several reasons are responsible for heat accumulation in PBSSB includes low thermal conductivity of biomass, absence of free water, channeling, etc. [5]. Channeling occurs when the fluid/gas flowing through the packed bed and find a 'preferred or fix path' through the bed.

The current research work focuses on novel design of PBSSB. Experiments are carried out to study the heat accumulation at different heights of PBSSB and to analyze the $\mathrm{C}: \mathrm{N}$ ratio and protein content of unfermented and fermented samples. Aspergillus oryzae is chosen to be the micro-organism growing on jowar straw.

\section{Experimental Setup}

The experimental setup of a packed bed solid state fermentor is shown in Figure 1. It consists of a cylindrical unit (1) with a capacity of 4.4 litres. It is $25 \mathrm{~cm}$ long vertical cylinder with internal diameter of $15 \mathrm{~cm}$. The material used for the construction of fermentor system is 


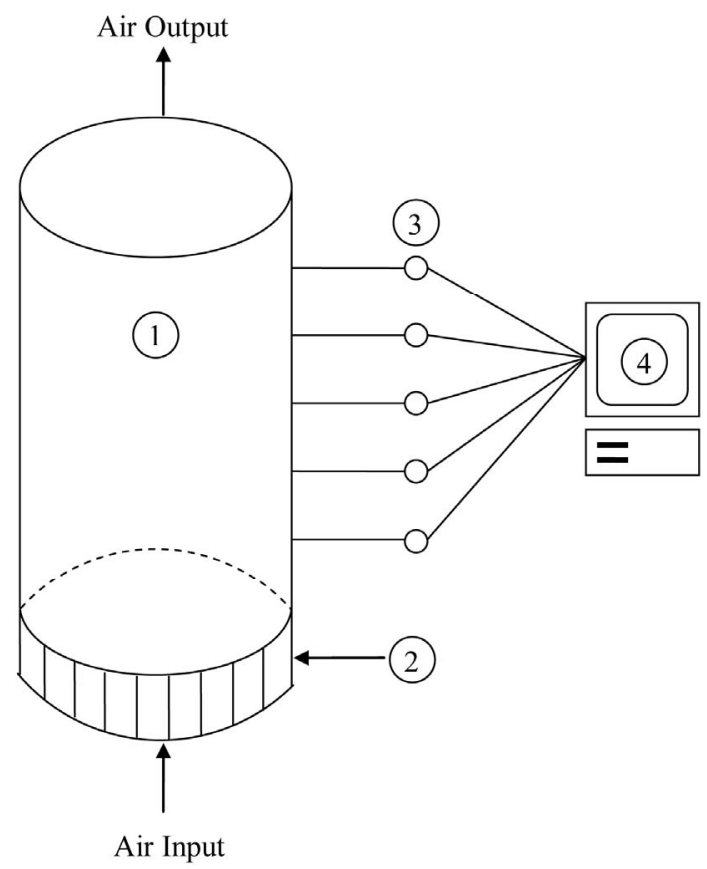

Figure 1. Packed-bed solid state bioreactor (PBSSB): (1) Fermentation vessel; (2) Wire mesh with glass wool; (3) PT100 thermocouple; (4) Data acquisition system.

thermocol. The base of fermentor is made up of wire mesh (2) with air distributor to facilitate aeration. The packed bed is aerated with a constant velocity of $0.2 \mathrm{~m} / \mathrm{s}$. The bed temperatures are measured by thermocouple PT100 (3) at different axial positions and recorded by a data acquisition system (4).

\section{Materials and Methods}

\subsection{Inoculum Preparation}

Spores of Aspergillus oryzae $\left(2 \times 10^{5}\right.$ spores per ml) are inoculated in Czapekdox broth having sucrose as carbon source and incubated for 48 hours at $30^{\circ} \mathrm{C}$. After incubation $5 \% \mathrm{v} / \mathrm{w}$ inoculums is inoculated in the cooked substrates.

\subsection{Pretreatment of Raw Material}

The known quantity of jowar straw is crushed in the mixer and screened to a mean particle size of $0.25 \mathrm{~cm}$ $0.27 \mathrm{~cm}$ for its utilization. The material is mixed with water and cooked in an autoclave at 1 bar for 30 minutes. The mixture is cooled to ambient temperature and then dried in a convection oven so that the moisture is maintained up to $50 \%-55 \%$. In the present work constant moisture is maintained and the effect of moisture content on growth of microorganism is assumed to be negligible. After drying, the mixture is inoculated with a spore suspension at a rate of $2 \times 10^{5}$ spores $/ \mathrm{ml}$ substrate dry matter (SDM). The mixture is also sprayed with a mineral solu- tion containing essential minerals like $\mathrm{MgSO}_{4}, \mathrm{KH}_{2} \mathrm{PO}_{4}$ and $\mathrm{FeSO}_{4}$. The mixture is then transferred in desired quantities into PBSSB. The initial $\mathrm{pH}$ of the biomass is measured with the method discussed by Chutmanop, Chuichulcherm, Chisti and Srinophakun [6] as given in Han and Anderson [7] and found to be 7.5.

\section{Results and Discussion}

The fermentation is carried out in PBSSB. The bioreactor is aerated with a velocity of $0.2 \mathrm{~m} / \mathrm{s}$ from the bottom of the column. This air is purified using 0.2 micron air filter before passing inside the column. The temperature at the centre of the bioreactor with a total depth of $12 \mathrm{~cm}$ as a function of time is shown in Figure 2. The temperature increases within a fermentation period $10-30 \mathrm{~h}$, except a slight decrease in the span of about $10-15 \mathrm{~h}$, probably due to presence of lag phase. In the lag phase, there is no heat evolution due to negligible growth of microorganism. The result indicates that the fermentation started at around $10 \mathrm{~h}$ and maximum metabolic activity phase is about 20 - $30 \mathrm{~h}$. During the active growth phase, the temperature increases from $34.5^{\circ} \mathrm{C}$ to $37.4^{\circ} \mathrm{C}$ due to high oxygen requirement and heat generation.

The temperature plots at various bed depths during the fermentation process are shown in Figure 3. The results indicate that the temperatures at all the bed depths increase gradually with the progress of fermentation process from $10-35 \mathrm{~h}$, and then decrease gradually. At the bed depths of $2 \mathrm{~cm}$ and $6 \mathrm{~cm}$, the maximum temperatures reached are $36.1^{\circ} \mathrm{C}$ and $36.4^{\circ} \mathrm{C}$ respectively during the fermentation period of $35 \mathrm{~h}$. While at the bed depths of $12 \mathrm{~cm}, 16 \mathrm{~cm}$ and $21 \mathrm{~cm}$, the maximum temperatures reached are $37.4^{\circ} \mathrm{C}, 37.6^{\circ} \mathrm{C}$ and $37.8^{\circ} \mathrm{C}$ respectively during the fermentation period of $30 \mathrm{~h}$, and then it is declined in a linear fashion to reach $35.1^{\circ} \mathrm{C}$ by about 15

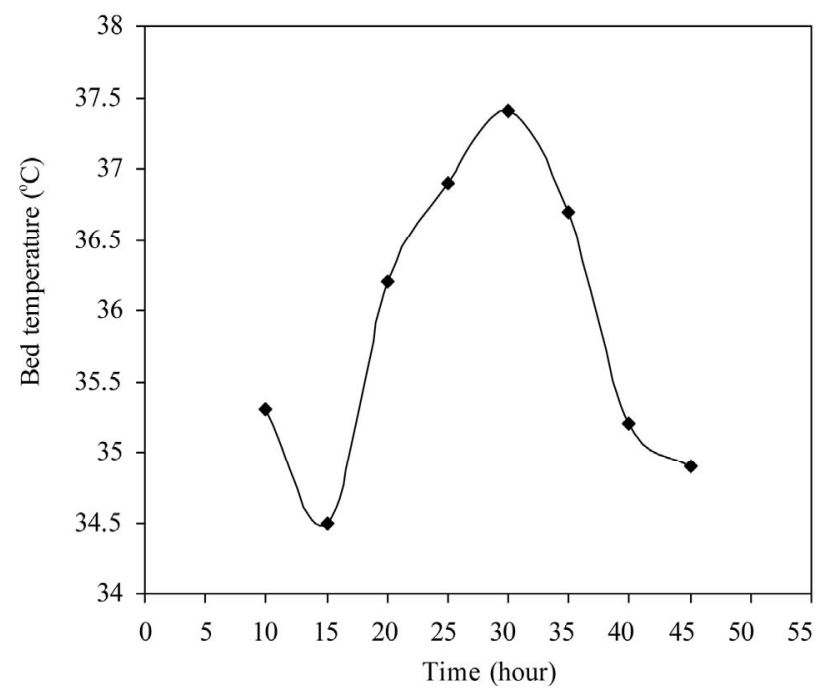

Figure 2. Temperature profile along the depth of the fermentor as function of time (Bed depth $=12 \mathrm{~cm})$. 


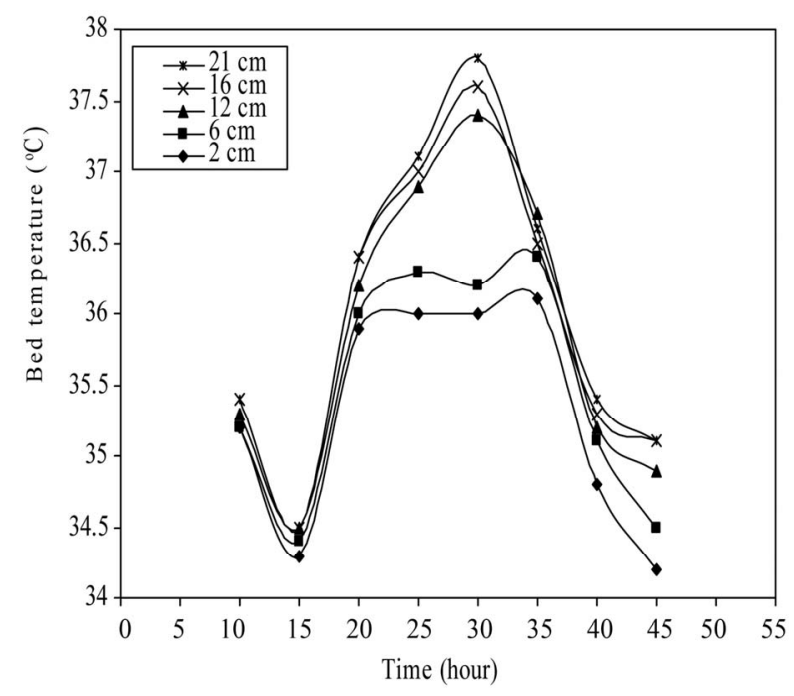

Figure 3. Temperature profiles at different bed depths of the fermentor as function of time.

hours corresponding to the completion of the fermentation process. Thus, it is found that the temperature gradient increase with the depth of the column. The results indicate that the bed depth also affected the temperature control in PBSSB. These results are in qualitative agreement with Chen, Xu \& Li [8], Fanaei \& Vaziri [9], Castaneda, Rojas, Bacquet, Raimbault \& Gonzalez [10] and Srinophakun \& Srinophakun [11]. Chen, Xu \& Li [8] developed the bioreactor for solid-state fermentation (SSF) and performed the temperature gradient studies with different bed heights. Fanaei \& Vaziri [9], Castaneda, Rojas, Bacquet, Raimbault \& Gonzalez [10] and Srinophakun \& Srinophakun [11] developed the mathematical model for packed-bed solid-state fermentation to study the effects of various design and operating variables.

Tables 1 and 2 indicate the results of jowar straw samples before and after fermentation respectively. The samples are analyzed to find $\mathrm{C}: \mathrm{N}$ ratio and protein content before and after fermentation. The C:N ratio above 16 is suitable for the growth of micro-organism in the fermentation process [12]. Carbon source represents the energetic source that will be available for the growth of the micro-organism. As indicated in Table 1, the C:N ratio of jowar straw sample is 18.45 and hence it is suitable biomass for fermentation process. The protein content in the biomass is analyzed by the standard method used for the determination of protein in foods and feeds (IS:7219:1973). It is found that the protein content of fermented biomass is increased to $9.6(\% \mathrm{w} / \mathrm{w})$ from the initial value of $3.44(\% \mathrm{w} / \mathrm{w})$ of unfermented biomass. This protein rich biomass has high demand as the nutritional animal feed. This result is in agreement with Han and Anderson [7]. Han and Anderson [7] carried semi-
Table 1. Laboratory test results of jowar straw sample before fermentation.

\begin{tabular}{ccccc}
\hline Sr. No. & $\begin{array}{c}\text { Test } \\
\text { Parameters }\end{array}$ & $\begin{array}{c}\text { Measurement } \\
\text { Unit }\end{array}$ & Method & Result \\
\hline 1 & $\begin{array}{c}\text { Organic } \\
\text { Carbon }\end{array}$ & \% w/w & $\begin{array}{c}\text { SW 8-Method } \\
\text { 9060A }\end{array}$ & 10.15 \\
2 & Nitrogen & \% w/w & IS:7219:1973 & 0.55 \\
3 & C:N Ratio & - & By Calculation & 18.45 \\
4 & Protein & $\%$ w/w & IS:7219:1973 & 3.44 \\
\hline
\end{tabular}

Table 2. Laboratory test results of jowar straw sample after fermentation.

\begin{tabular}{ccccc}
\hline Sr. No. & $\begin{array}{c}\text { Test } \\
\text { Parameters }\end{array}$ & $\begin{array}{c}\text { Measurement } \\
\text { Unit }\end{array}$ & Method & Result \\
\hline 1 & $\begin{array}{c}\text { Organic } \\
\text { Carbon }\end{array}$ & \% w/w & $\begin{array}{c}\text { SW 8-Method } \\
\text { 9060A }\end{array}$ & 5.44 \\
2 & Nitrogen & \% w/w & IS:7219:1973 & 1.54 \\
3 & C:N Ratio & - & By Calculation & 3.53 \\
4 & Protein & $\%$ w/w & IS:7219:1973 & 9.6 \\
\hline
\end{tabular}

solid fermentation on ryegrass straw and found fourfold increase in the protein content.

\section{Conclusion}

The packed bed solid state bioreactor is constructed to study the effects of heat accumulation and protein content in jowar straw. It is found that the temperature gradient increase gradually with increase in bed depth. The results indicate that the maximum metabolic activity phase is $20-30 \mathrm{~h}$ during which heat generation is more. The fermented sample is analyzed for protein content. It is found that protein content of jowar straw increases from $3.44(\% \mathrm{w} / \mathrm{w})$ to $9.6(\% \mathrm{w} / \mathrm{w})$. This indicates the applicability of PBSSB for protein enrichment of biomass and its direct applicability for animal feed. PBSSB developed in the present study is suitable for closed static fermentation to get value added biomass. It can be further modified to other biomass materials and microorganisms systems where product has high added value.

\section{Acknowledgements}

The author would like to thank to the University Grants Commission (UGC), India for financially supporting the minor research project in physical sciences, biosciences, maths, medical, agriculture sciences and engineering \& chemistry to university/college teacher. This project is supported by UGC under the project entitled "Temperature gradient studies in packed bed solid state fermentor-F. No. 39-1013/2010 (SR)”. 


\section{REFERENCES}

[1] T. Robinson and P. Nigam, "Bioreactor Design for Protein Enrichment of Agricultural Residues by Solid State Fermentation," Biochemical Engineering Journal, Vol. 13, No. 2, 2003, pp. 197-203. doi:10.1016/S1369-703X(02)00132-8

[2] A. Pandey, "Solid-State Fermentation," Biochemical Engineering Journal, Vol. 13, No. 2, 2003, pp. 81-84. doi:10.1016/S1369-703X(02)00121-3

[3] A. Prabhakar, K. Krishnaiah, J. Janaun and A. Bono, “An Overview of Engineering Aspects of Solid State Fermentation,” Malaysian Journal of Microbiology, Vol. 1, No. 2, 2005, pp. 10-16. doi:web.usm.my/mjm/issues/vol1no2

[4] R. R. Singhania, A. K. Patel, C. R. Soccol and A. Pandey, "Recent Advances in Solid-State Fermentation," Biochemical Engineering Journal, Vol. 44, No. 1, 2009, pp. 13-18. doi:10.1016/j.bej.2008.10.019

[5] M. Khanahmadi, R. Roostaazad, D. A. Mitchell, M. Miranzadeh, R. Boxorgmehri and A. Safekordi, "Bed Moisture Estimation by Monitoring of Air Stream Temperature Rise in Packed-Bed Solid State Fermentation," Chemical Engineering Science, Vol. 61, No. 17, 2006, pp. 5654-5663. doi:10.1016/j.ces.2006.04.039

[6] J. Chutmanop, S. Chuichulcherm, Y. Chisti and P. Srinophakun, "Protease Production by Aspergillus orgyzae in Solid State Fermentation Using Agroindustrial Substrates," Journal of Chemical Technology and Biotechnology, Vol. 83, No. 7, 2008, pp. 1012-1018. doi:10.1002/jctb.1907

[7] Y. W. Han and A. W. Anderson, "Semisolid Fermentation of Ryegrass Straw,” Applied and Environmental Microbiology, Vol. 30, No. 6, 1975, pp. 930-934. doi:30/6/930

[8] H. Z. Chen, J. Xu and Z. H. Li, “Temperature Control at Different Bed Depths in a Novel Solid-State Fermentation System with Two Dynamic Changes of Air,” Biochemical Engineering Journal, Vol. 23, No. 2, 2005, pp. 117-122. doi:10.1016/j.bej.2004.11.003

[9] M. A. Fanaei and B. M. Vaziri, "Modeling of Temperature Gradients in Packed-Bed Solid-State Bioreactors," Chemical Engineering and Processing: Process Intensification, Vol. 48, No. 1, 2009, pp. 446-451. doi:10.1016/j.cep.2008.06.001

[10] G. S. Castaneda, M. G. Rojas, G. Bacquet, M. Raimbault and G. V. Gonzalez, "Heat Transfer Simulation in Solid Substrate Fermentation," Biotechnology and Bioengineering, Vol. 35, No. 8, 1990, pp. 802-808. doi:10.1002/bit.260350808

[11] P. Srinophakun and T. Srinophakun, "Bioreactor Performance and Design of Large Scale Packed-Bed SolidState Fermentation,” Kasetsart Journal (Natural Science), Vol. 32, No. 1, 1998, pp. 333-338. doi:A0804281119456603

[12] A. Pandey, C. R. Soccol and C. Larroche, "Current Development in Solid-State Fermentation," Springer, New Delhi, 2008. doi:10.1007/978-0-387-75213-6 